\title{
A CORRELATION BETWEEN THE FLUCTUATIONS OF CYTOKINE CONCENTRATIONS MEASURED IN THE MORNING AND EVENING AND THE CIRCADIAN BLOOD PRESSURE RHYTHM IN PATIENTS WITH STAGE II ESSENTIAL HYPERTENSION
}

\author{
Radaeva $\mathrm{OA}^{1 \otimes}$, Simbirtsev $\mathrm{AS}^{2}$, Khovryakov $\mathrm{AV}^{3}$ \\ ${ }^{1}$ National Research Mordovia State University, Saransk, Russia \\ 2 State Research Institute of Highly Pure Biopreparations, FMBA, St. Petersburg, Russia \\ ${ }^{3}$ Mordovian Republican Clinical Hospital No.4, Saransk, Russia
}

\begin{abstract}
Today, increasing attention is being paid to the role of circadian rhythms in pathology. There are time-of-day-dependent immune markers that provide valuable information about disease progression. The aim of this study was to measure evening and morning concentrations of a few cytokines (interleukins, adhesion molecules, tumor necrosis/growth factors, etc.) in the peripheral blood of patients with stage II essential hypertension and to investigate how they correlate with a nocturnal blood pressure decline. Blood samples were collected from 90 patients with stage II EH at 7:00 a.m. and 8:00 p.m. Cytokine concentrations were measured using immunoassays. Based on 24-h blood pressure monitoring, the patients were distributed into 3 groups: dippers, non-dippers and night-peakers. The morning to evening ratios of cytokine concentrations in patients with EH differed from those in healthy controls due to an increase in the evening concentrations of somnogenic cytokines (IL1 $\beta, I L 1 \alpha)$ and LIF, sLIFr, and M-CSF whose daily fluctuations patterns remain understudied. On the whole, the fluctuation patterns of the measured cytokines in patients with stage II EH who had had the condition for 10 to 14 years and were receiving no antihypertensive treatment at the time of our study differed from those displayed by healthy controls. A twenty percent rise in the evening concentrations of IL1a, LIF, SLIFr, M-CSF, and erythropoietin contributes significantly to pathological blood pressure rhythms (as demonstrated by the groups of non-dippers and night-peakers) in patients with stage II EH receiving no antihypertensive therapy. Understanding the pathophysiological role of cytokine levels and their fluctuations over a 24-h cycle could inspire new methods for EH prevention and reduce end-organ damage.
\end{abstract}

Keywords: cytokines, essential hypertension, Dipper, Non-dipper, Night-peaker

Author contribution: Radaeva OA recruited the study participants, collected blood samples, interpreted the results, analyzed the literature, and helped to write a draft of the manuscript. Simbirtsev AS supervised the research group, identified the aims and objectives of the study, proposed a methodology, and provided critical feedback. Khovryakov AV recruited the study participants, collected blood samples and wrote the manuscript.

Compliance with ethical standards: the study was approved by the Ethics Committee of Ogariov Mordovian State University (Protocol 12 dated December $14,2008)$. All patients gave their informed consent to participate. Blood samples were collected in full compliance with the Declaration of Helsinki (2000) and the Protocol of the Convention on Human Rights and Biomedicine of the Council of Europe (1999).

$\triangle$ Correspondence should be addressed: Olga A. Radaeva

Ulianova 26/a, Saransk, 430030; vtlbwbyf_79@mail.ru

Received: 16.07.2018 Accepted: 01.03.2019 Published online: 12.03.2019

DOI: 10.24075/brsmu.2019.011

\section{СВЯЗЬ СУТОЧНЫХ КОЛЕБАНИЙ СОДЕРЖАНИЯ ЦИТОКИНОВ С ИЗМЕНЕНИЕМ РИТМОВ АРТЕРИАЛЬНОГО ДАВЛЕНИЯ ПРИ ЭССЕНЦИАЛЬНОЙ АРТЕРИАЛЬНОЙ ГИПЕРТЕНЗИИ ВТОРОЙ СТАДИИ}

\author{
О. А. Радаева ${ }^{1}$, А. С. Симбирцев², А. В. Ховряков
}

'Мордовский государственный университет имени Н. П. Огарева, Саранск, Россия

2 Государственный научно-исследовательский институт особо чистых биопрепаратов Федерального медико-биологического агентства, Санкт-Петербург, Россия

${ }^{3}$ ГБУЗ РМ «Республиканская клиническая больница № 4», Саранск, Россия

\begin{abstract}
Все больше внимания уделяется исследованию роли суточных ритмов в патологических процессах в организме. Безусловно, существуют суточные иммунные маркеры, позволяющие судить о прогрессировании ряда заболеваний. Целью исследования было изучить содержание цитокинов (интерлейкинов, молекул адгезии, факторов некроза опухоли, роста и др.) в сыворотке перисерической крови больных эссенциальной артериальной гипертензией (ЭАГ) II стадии в утреннее/вечернее время и его корреляцию со степенью снижения артериального давления (АД) в ночное время. У 90 пациентов с ЭАГ ІІ стадии проводили забор крови в 7.00 и 20.00 ч, определяли иммуноферментным методом в сыворотке перисерической крови цитокины и проводили анализ данных суточного мониторирования АД с выделением групп: «Dipper», «Non-dipper», «Night-peaker». Обнаружено изменение отношения утренних и вечерних концентраций при сравнении со здоровыми, за счет повышения степени роста в вечернее время как цитокинов

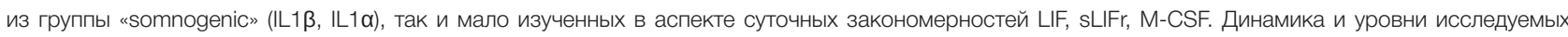
показателей у пациентов с ЭАГ ॥ стадией и анамнезом заболевания 10-14 лет без гипотензивной терапии отличались от таковых в группе здоровых добровольцев (контроля). Повышение концентраций IL1a, LIF, sLIFr, M-CSF, эритропоэтина в 20.00 ч на 20\% и более является значимым компонентом формирования патологических околосуточных ритмов АД («Non-dipper» и «Night-peaker») у больных ЭАГ II стадии при длительности заболевания 10-14 лет (без приема гипотензивных препаратов). Понимание патофизиологической роли изменения не только количественных характеристик цитокинов сыворотки периферической крови у больных ЭАГ ІІ стадии, но и особенностей их суточной динамики может стать основой создания новых систем профилактики прогрессирования ЭАГ и снизить частоту повреждения органов-мишеней.
\end{abstract}

Ключевые слова: цитокины, эссенциальная артериальная гипертензия, «Dipper», «Non- dipper», «Night-peaker»

Информация о вкладе авторов: О. А. Радаева: набор группы пациентов, забор материала для исследования, интерпретация результатов исследования и литературных данных, подготовка первоначального варианта текста статьи, компьютерная работа с текстом; А. С. Симбирцев: научное руководство, определение цели и задач, методологии исследования, критический анализ полученных результатов и доработка текста; А. В Ховряков: набор группы пациентов, забор материала для исследования, компьютерная работа с текстом.

Соблюдение этических стандартов: исследование одобрено этическим комитетом ФГБОУ «МГУ им. Н. П. Огарева» (протоколы № 12 от 14 декабря 2008 г.); отбор биологического материала для исследования (кровь) произвели с учетом положений Хельсинской Декларации ВМА (2000) и протокола Конвенции Совета Европы о правах человека и биомедицине (1999); все участники исследования подписали добровольное информированное согласие на участие в эксперименте.

$\bigotimes$ Для корреспонденции: Ольга Александровна Радаева ул. Ульянова, д. 26а, г. Саранск, 430030; vtlbwbyf_79@mail.ru

Статья получена: 16.07.2018 Статья принята к печати: 01.03.2019 Опубликована онлайн: 12.03.2019

DOI: $10.24075 /$ vrgmu.2019.011 
Circadian rhythms are adaptive oscillations in behavior and physiology that follow a roughly 24-h cycle and prepare an organism for the environmental effects of the Earth's rotation [1]. The circadian clock originated in cyanobacteria and is found in all multicellular organisms and mammals in particular. In 2017, the Nobel prize in physiology or medicine was awarded to Jeffrey C. Hall, Michael Rosbash and Michael W. Young "for their discoveries of molecular mechanisms controlling the circadian rhythm". This award has emphasized the importance of research into the role of daily cycles in health and pathology. In 1960 Halberg et al. articulated the basic principles of circadian rhythm research in immunology after discovering a circadian pattern of sensitivity to an endotoxin administered to mice at different times of day. The sleep/wake cycle is one of the most well-studied manifestations of the circadian rhythm, correlating with the immune response and blood pressure (BP) dynamics [2]. It is currently assumed that proinflammatory cytokines are somnogenic, i.e. increasingly synthesized during the resting phase, whereas anti-inflammatory cytokines, such as IL10, are activated upon awakening and inhibit sleep. In this respect, IL1 $\beta$, TNF $\alpha$, IFNy, IL6, IL4, and IL10 are currently the best studied [1, 3, 4, 5]. Blood pressure control is exerted by the following neuroendocrine mechanisms: the monoaminergic systems that regulate the physiological activity of the autonomous nervous system and the secretion of biogenic amines; the hypothalamic-pituitary-adrenal and hypothalamicpituitary-thyroid axes; the opioid, renin-angiotensin-aldosterone and endothelial systems, and vasoactive peptides [6, 7]. Recently, there has been growing interest in circadian rhythms and their effect on the immune system, but in spite of significant advances in the understanding of their mechanisms, many circadian phenotypes are yet to be explained. A number of experimental studies have suggested an association between the fluctuations of cytokine levels at different times of day and end-organ damage [8] and also a nocturnal decline in BP [9]. Progredient essential hypertension (EH) accompanied by stably high BP with very slight fluctuations in the evening correlates with the levels of certain cytokines. This suggests the existence of time-of-day-dependent immune markers that promote cardiovascular diseases and provides rationale for our study. This work aims to investigate the association between the morning/evening levels of certain cytokines (interleukins, adhesion molecules, tumor necrosis/growth factors, etc.), as well as erythropoietin, in the peripheral blood of patients with stage II EH and the nocturnal BP decline registered in such patients.

\section{METHODS}

The study was carried out at the facilities of the Regional Vascular Center of Mordovian Republican Clinical Hospital No.4, Mordovian Republican Clinical Hospital No.3 and the Department of Immunology, Microbiology, and Virology of Ogariov Mordovian State University. The study recruited 90 patients (40 men and 50 women). Fifty healthy volunteers with no signs of $\mathrm{EH}$ constituted the control group. The groups were comparable in terms of age and sex. The following inclusion criteria were applied: age of $57.5 \pm 1.17$ years; stage II EH (duration of 10 to 14 years); no antihypertensive treatment received. Exclusion criteria included comorbidities; types I and II diabetes mellitus; metabolic syndrome; autoimmune disorders; allergies; symptomatic therapy aimed to normalize blood pressure; infections 1 month before the study; alcoholism or drug addiction; refusal to participate in the study. Peripheral blood samples were collected from the patients and healthy controls at 7:00 a.m. and 20:00 p.m. The interval between blood collection and meals was at least $6 \mathrm{~h}$. The following cytokines were assayed: IL1 $\beta$, IL1 $\alpha$, IL1ra, IL18, IL18BP, IL37, IL6, sIL6r, LIF, sLIFr, TNF $\alpha$, sTNF-RI, IL2, IL10, TGF- $\beta 1$, IL8, CX3CL1, CXCL10, INFy, M-CSF, erythropoietin, and a few vasoactive peptides, including NO, iNOS, eNOS, ADMA, SDMA, NtproCNP, and Nt-proBNP. In $20 \%$ of patients, blood sampling was repeated a month later to test the reproducibility of the results. The variance was 3 to $6 \%$. Time for blood collection was chosen based on the literature $[1,8,10]$ and our own pilot study which we had conducted in 5 healthy individuals and 24 patients with stage II EH with different circadian BP rhythms. In that study, we had analyzed the levels of 6 cytokines, including IL1 $\alpha$, LIF, sLIFr, M-CSF, and erythropoietin, measured at 6:00 a.m., 8:00 a.m., 12:00 a.m., 4:00 p.m., 8:00, and midnight.

Peripheral blood concentrations of the studied cytokines and vasoactive peptides were determined with ELISA using the Personal Lab TM analyzer (Adaltis; Italy) at the laboratory of the Department of Immunology (Ogariov Mordovian State University; laboratory license 13.01.04. 0001.L.000005.06.11 issued 23.06.2011).

All study participants had their blood pressure monitored at the Regional Vascular Center of the Mordovian Republican Clinical Hospital 4 and Mordovian Republican Clinical Hospital 3 using Space Labs Medical 90702 (Spacelabs Medical, Inc.; USA) according to the recommendations of the Fourth International Consensus Conference on Ambulatory Blood Pressure Monitoring (Belgium, 1994); the obtained blood pressure values were added to the patients' medical histories. The patients were divided into 3 groups depending on the degree of BP fluctuations at night: dippers (10-20\% decline), non-dippers (< 10\% decline); night-peakers (elevated BP).

The data were processed in Statistica ver. 8.0. (StatSoft Inc.; USA). Normality of data distribution was tested using the one-sample Kolmogorov-Smirnoff test. If the distribution was normal, the data were presented as an arithmetic mean (M) and a standard deviation (SD); if the distribution deviated from the norm, the data were presented as a median $(\mathrm{Me})$ and the interquartile range (C25-C75). Depending on the normality of data distribution and the sample size, the two-sample t-test and the Mann-Whitney U-test were used to compare unrelated samples; related samples were analyzed using the paired t-test and Wilcoxon signed rank test.

\section{RESULTS}

The patients with stage II EH who had been suffering from this condition for 10 to 14 years and were not receiving antihypertensive therapy around the time of the study, had higher morning concentrations of IL1 $\beta, I L 1 \alpha, I L 18$, IL18BP, IL6, sIL6r, LIF, TNF $\alpha$, sTNF-RI, IL10, TGF- $\beta 1$, IL8, CX3CL1, CXCL10, INFy, M-CSF, and erythropoietin $(p<0.001)$ and lower morning concentrations of IL1ra $(p<0.001)$ than the healthy controls (Table 1). The following dynamics were observed in the control group in the evening: IL1 $\beta$ levels rose by $14.1 \%(0.37), p<0.05$; IL1a, by 14.8\% (0.33), $p<0.05$; IL6, by 29.2\% (0.98), $p<0.001$; TNFa, by $12.3 \%$ (0.78), $p<0.01$; sTNF-RI, by $12.6 \%(0.65)$, $p<0.05$; IL1ra dropped by $14.6 \%$ (0.32), $p<0.01$; IL10, by $23 \%$ (0.58), $p<0.01$, and sIL6r, by 30.4\% (1.54), $p<0.001$. In the patients with stage $\| \mathrm{EH}$ the pattern was the same as in the controls, but the changes were more pronounced: IL1 $\beta$ concentrations rose by $21.3 \%$ (0.92), $p<0.001$ and IL $1 \alpha$, by $31.2 \%$ (1.12), $p<0.001$. The most significant, clinically relevant differences registered in the group of patients with $\mathrm{EH}$ were observed for LIF concentrations that increased by $16 \%(0.43)$, 
$p<0.01$, and for sLIFr that demonstrated a $22 \%$ rise $(0.63)$, $p<0.001$. In our hypertensive patients, M-CSF levels increased by $20.2 \%(0.42), p<0.001$, and erythropoietin, by $36.5 \%$ (1.22), $p<0.001$, whereas IL18BP concentrations declined by $11 \%$ (0.27), $p<0.05$ and IL37, by $21.7 \%$ (0.86), $p<0.001$, in contrast to the control group. The evening rise in the IL6 and TNF $\alpha$ concentrations was comparable between the two groups: IL6 levels surged by 31\% (1.02) and 29.2\% (0.98), $p<0.001$, respectively, while TNFa levels rose by $12.3 \%$ $(0.78)$ and $12.2 \%(0.66), p<0.01)$, respectively. In the healthy volunteers, slL6r levels decreased in the evening $(p<0.001)$, attenuating IL6 activity after 8 p.m. In contrast, the patients with elevated blood pressure did not have this protective sIL6r decline. The analysis of evening IL10 concentrations revealed a comparable decline $(p<0.01)$ in the levels of this proinflammatory cytokine between the groups, which reached $17 \%(0.58)$ and $15 \%(0.63)$ in the healthy individuals and patients with $\mathrm{EH}$, respectively.

The analysis of concentrations of cytokines and vasoactive peptides measured at different times of day yielded strong direct correlations between the evening concentrations of IL1 $\alpha$ and ADMA, $r=0.76, p<0.01$ (for their diurnal levels $r=0.58$, $p<0.05$ ); sLIFr and SDMA, $r=0.85, p<0.001$ (for their diurnal levels $r=0.69, p<0.05$ ); beM-CSF and SDMA, $r=0.81, p<0.01$ (for their diurnal levels $r=0.51, p<0.05$ ). The strength and the direction of correlations between the levels of IL1 $\beta$, IL1ra, IL18, IL18BP, IL37, IL6, sIL6r, LIF, TNFa, sTNF-RI, IL2, IL10, TGF- $\beta 1$, IL8, CX3CL1, CXCL10, INFy, and the concentrations of vasoactive peptides in the blood serum measured in the evening did not differ from the results obtained for the samples that were collected at 7:00 a.m.

A pronounced increase in the concentrations of the cytokines that correlated with vasopressor factors in patients with stage II EH suggests that there might be a correlation between the morning/evening levels of these cytokines and the BP phenotypes (dipper, non-dipper and night-peaker).

The dippers, whose BP dropped by normal 10-20\% at nighttime, as well as other patients with stage $\mathrm{II} \mathrm{EH}$, had higher concentrations of proinflammatory cytokines. In this subgroup, the dynamics observed for IL1 $\beta$, IL18, IL18BP, IL37, LIF, sLIFr, TNFa, sTNF-RI, IL2, IL8, IL10, IFNy, CX3CL1, CXCL10, TGF 31 , and M-CSF were the same as in the healthy individuals (Table 2). Only 6 cytokines demonstrated a different behavior: IL6 and slL6r (a less pronounced rise in IL6 in the evening accompanied by high and stable sIL6r concentrations); protective IL1ra and erythropoietin that did not decline as in the healthy volunteers; elevated evening IL $1 \alpha$ that demonstrated a more than $20 \%$ rise in comparison with its morning concentrations. The analysis of the cyclic dynamics demonstrated by 21 studied cytokines established that evening deviations from morning concentrations by more than $20 \%$ were the most pathogenic in terms of their contribution to the progression of hypertension. In the dipper group, such deviations were observed only for IL $1 \alpha$ associated with increased ADMA in patients with stage II EH.

The non-dippers, whose BP dropped by only $10 \%$ at the most, demonstrated a more pronounced change in cytokine concentrations in the evening than the healthy controls and the dippers (Table 2). Only 9 cytokines followed a similar pattern

Table 1. Morning and evening concentrations of cytokines $(\mathrm{pg} / \mathrm{ml}$ ) in the serum samples of patients with stage II EH (duration of 10 to 14 years, no antihypertensive treatment applied)

\begin{tabular}{|c|c|c|c|c|}
\hline \multirow{3}{*}{ Cytokines } & \multicolumn{2}{|c|}{ Healthy controls $(n=50)$} & \multicolumn{2}{|c|}{ Patients with stage II EH $(n=90)$} \\
\hline & 7.00 a.m. & 8:00 p.m. & 7.00 a.m. & 8:00 p.m. \\
\hline & 1 & 2 & 3 & 4 \\
\hline IL1 $\beta$ & $5.2(1.87)$ & $5.95(1.37)^{\prime 1}$ & $18.7(5.8)^{\star 1}$ & $22.8(6.12)^{\star 2.3}$ \\
\hline IL1 $\alpha$ & $3.83(1.17)$ & $4.37(0.98)^{\prime 1}$ & $13.2(3)^{\star 1}$ & $17.2(2.93)^{\star 2.3}$ \\
\hline IL1ra & 691 (99) & $598(96)^{\wedge 1}$ & $575(108)^{\star 1}$ & 582 (96.2) \\
\hline IL18 & 197 (59) & $201(48)$ & $371(84)^{* 1}$ & $382(83)^{\star 2}$ \\
\hline IL18BP & 4934 (1173) & $4903(1122)$ & $6710(1980)^{\star 1}$ & $5970(1783)^{\wedge 2.3}$ \\
\hline IL37 & $90(25.6)$ & $88(17.3)$ & $92(24.5)$ & $71.6(18.2)^{\prime 1}$ \\
\hline IL6 & $3.12(0.63)$ & $4.03(0.69)^{* 1}$ & $23.7(4.2)^{* 1}$ & $27.2(3.92)^{* 2.3}$ \\
\hline slL6r & $681(52)$ & $478(50)^{\star 1}$ & $1826(263)^{* 1}$ & $1902(255)^{\star 2}$ \\
\hline LIF & $1.41(0.61)$ & $1.47(0.54)$ & $7.54(2.4)^{\star 1}$ & $9.08(2.24)^{* 2.3}$ \\
\hline sLIFr & $3920(1123)$ & $4003(1223)$ & $4100(1200)$ & $5100(1420)^{\star 2.3}$ \\
\hline TNF- $\alpha$ & $7.56(1.83)$ & $8.49(1.64)^{\wedge 1}$ & $21.4(4)^{\star 1}$ & $23.2(3.84)^{\star 2 \wedge 3}$ \\
\hline sTNF-RI & $1620(367)$ & $1817(367)^{\prime 1}$ & $2770(670)^{* 1}$ & $2810(627)^{\star 2}$ \\
\hline IL2 & $10.1(2.12)$ & $10.7(1.97)$ & $10.8(3.11)$ & $10.4(2.82)$ \\
\hline IL8 & $8.75(1.82)$ & $9.21(2.03)$ & $29(7.83)^{\star 1}$ & $31.2(6.61)^{\star 2}$ \\
\hline IL10 & $18.2(5.7)$ & $15.9(4.83)^{\wedge 1}$ & $26.2(7.9)^{\star 1}$ & $22.3(6.87)^{* 213}$ \\
\hline IFNy & $8.97(2.23)$ & $8.84(2.14)$ & $18.4(4.3)^{\star 1}$ & $18.7(3.96)^{\star 2}$ \\
\hline M-CSF & $202(51)$ & $197(47)$ & $389(92)^{\star 1}$ & $463(87)^{\star 2.3}$ \\
\hline CX3CL1 & $422(61.3)$ & $436(58.1)$ & $520(120)^{\star 1}$ & $503(112)^{\wedge 2}$ \\
\hline CXCL10 & $8.83(1.73)$ & $8.97(1.24)$ & $18.2(4.5)^{\star 1}$ & $17.9(3.84)^{\star 2}$ \\
\hline TGF $\beta 1$ & $11.5(3.23)$ & $10.2(2.84)$ & $21.4(4.64)^{* 1}$ & $20.2(4.24)^{\star 2}$ \\
\hline Erythropoietin & $3.93(1.31)$ & $4.27(1.01)$ & $12.6(3.8)^{\star 1_{1}}$ & $17.2(3.43)^{\star 2.3}$ \\
\hline
\end{tabular}

Note: significance of differences: ' $-<0.05, \wedge-<0.01,{ }^{*}-<0.001$ (comparison with the specified group). The data are presented as an arithmetic mean (M) and a standard deviation (SD). 
of morning-to-evening changes as in the healthy controls, including IL18, TNFa, sTNF-RI, IL2, IL8, IFNy, TGFß1, CX3CL1, and CXCL10. Evening deviations from morning concentrations reaching over 20\% were observed for IL1 $\beta$, IL1 $\alpha$, IL37, LIF, sLIFr, IL10, M-CSF, and erythropoietin and were statistically significant between the non-dippers and the healthy controls. IL37 and IL10, which might be protective against the progression of $\mathrm{EH}$, as suggested by the study results, demonstrated a more pronounced evening drop in the patients with insufficiently low nocturnal BP than in the healthy individuals. In contrast IL1 $\beta, I L 1 \alpha$, LIF, sLIFr, M-CSF, and erythropoietin concentrations tended to grow in the evening in such patients. It should be noted that evening and morning levels of IL1ra in the nondippers did not differ, whereas a significant IL1ra decline was observed in the controls, suggesting protection against rising ILI $\beta$ and IL1 $\alpha$, just like in the dippers.

In the night-peakers with elevated nocturnal BP, the daily dynamics of IL1ra, IL18, TNFa, sTNF-RI, IL2, IL8, CX3CL1, CXCL10, and TGF $\beta 1$ were similar to those observed in the controls (Table 2). Evening deviations from morning concentrations reaching over $20 \%$ were noticed for IL $1 \beta$, IL1 $\alpha$, IL37, LIF, sLIFr, M-CSF, neopterin, and erythropoietin and were statistically significant between the night-peakers and the healthy controls. IL37, which could be relatively protective against the progression of hypertension in patients with elevated BP, exhibited a more pronounced evening decline as compared to the controls, whereas for IL1 $\beta$, IL $1 \alpha$, LIF, sLIFr, $\mathrm{M}-\mathrm{CSF}$, neopterin and erythropoietin, a more pronounced rise was observed. It should be noted that in the night-peakers, IL10 concentrations did not differ between morning and evening, although they did go down in the healthy controls; this tendency might be protective against the rising levels of proinflammatory cytokines. In our study, the cytokine synthesis pattern was similar in the night-peakers and the non-dippers, differing only in the behavior of IL1ra. The evening concentrations of this cytokine dropped significantly in the night-peakers; however, proinflammatory IL10 did not drop at all, which was not the case with the non-dippers. This makes the night-peaker and non-dipper groups somewhat equivalent in terms of protection against $\mathrm{EH}$ progression. In the night-peakers, the evening levels of IL1 $\alpha, M-C S F$ and erythropoietin increased more than in the non-dippers (> 35\% at 8:00 p.m.), but the overall pattern of their dynamics was the same.

\section{DISCUSSION}

Cytokines, including IL1 $\beta$, TNFa, IFNy, IL6, IL4, and IL10, affect the biological activity of neurotransmitters/neuromodulators and exert a direct effect on neurons in some areas of the brain, regulating the sleep cycle, which remains the most wellstudied circadian rhythm [2]. This means that these cytokines are involved in the processes indirectly related to the sleep/ wake cycle, including blood pressure fluctuations. We have found that the daily dynamics of cytokine concentrations is abnormal in patients with stage II EH (duration of 10 to 14 years) in comparison with healthy controls: concentrations of somnogenic

Table 2. The relationships between morning and evening concentrations of cytokines $(\mathrm{pg} / \mathrm{ml})$ in the serum samples of patients with stage II EH (duration of 10 to 14 years, no antihypertensive treatment applied) AND the blood pressure phenotype

\begin{tabular}{|c|c|c|c|c|c|c|}
\hline \multirow{3}{*}{ Cytokines } & \multicolumn{2}{|c|}{ «Dipper» $(n=36)$} & \multicolumn{2}{|c|}{ «Non-dipper» $(n=30)$} & \multicolumn{2}{|c|}{ «Night-peaker» $(n=24)$} \\
\hline & 7.00 a.m. & 8:00 p.m & 7.00 a.m. & 8:00 p.m & 7.00 a.m. & 8:00 p.m \\
\hline & 1 & 2 & 3 & 4 & 5 & 6 \\
\hline IL1 $\beta$ & $16.3[3.24-25.1]$ & $18.7[10.3-29.4]^{\wedge 1}$ & 16.8 [3.32-26.4] & $22.3[15.6-32.8]^{\wedge 2 \star 3}$ & $22.4[10.4-32.2]^{\star 1} .^{3}$ & $29.4[18.9-36.3]^{\star 2.5 \wedge 4}$ \\
\hline IL1 $\alpha$ & 12.5 [5.72-17.3] & $15.2[10.4-21.3]^{\star 1}$ & 12.8 [5.23-17.9] & $17.3[13.8-23.1]^{\wedge 2 * 3}$ & $16.2[10.1-20.2]^{\star 1} .^{3}$ & $23.7[17.2-24.8]^{\star 2.5 .4}$ \\
\hline IL1ra & 570 [493-670] & 591 [517-691] & 567 [488-691] & 586 [504-652] & 589 [468-702] & 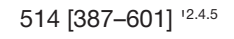 \\
\hline IL18 & 370 [311-432] & 400 [322-465] & 362 [291-421] & 407 [319-467] & 389 [298-444] & 397 [263-450] \\
\hline IL18BP & 6740 [5370-8457] & $5990[4700-7100]^{\wedge 1}$ & 6940 [5128-8620] & $6103[4620-7130]^{33}$ & 6630 [4970-8520] & $5930[4550-7310]^{15}$ \\
\hline IL37 & $87.5[70.2-110]$ & $82.3[59.3-109]$ & $90.1[67.5-106]$ & $60.4[32.2-83.3]^{\star 2} .^{3}$ & $85.4[68.7-114]$ & $62.5[33.4-80.9]^{\star 2.5}$ \\
\hline IL6 & 23.9 [20.8-26.7] & $27.2[24.5-29.9]^{\wedge 1}$ & 24.3 [20-26.9] & $27.7[24-29.3]^{\wedge 3}$ & 23.7 [21.2-26.5] & $26.8[24.8-30]^{\wedge 5}$ \\
\hline slL6r & 1826 [1648-2003] & 1902 [1730-2073] & 1793 [1615-2121] & 1837 [1710-2113] & 1804 [1583-2107] & 1924 [1698-2107] \\
\hline LIF & 8.07 [4.68-10.3] & 8.56 [6.86-9.93] & 7.09 [4.92-9.12] & $10.8[9.92-12.1]^{\wedge 2 * 3}$ & 8.32 [5.13-9.3] & $11.3[8.43-12.9]^{\star 2.5}$ \\
\hline sLIFr & 4140 [3120-4820] & 4320 [3270-5240] & 4060 [3230-4770] & $5930[4600-7720]^{\star 2} .^{3}$ & 3980 [3040-4910] & $6030[4580-7810]^{\star 2.5}$ \\
\hline TNF- $\alpha$ & 21.2 [18.3-24] & $23.6[20.9-26.1]^{\wedge 1}$ & 20.7 [18.9-23.5] & $23.1[20.2-25.7]^{\wedge 3}$ & 20.9 [17.9-24.3] & $23.9[21.6-26.7]^{\wedge 5}$ \\
\hline sTNF-RI & 2790 [2320-3220] & $3030[2607-3450]^{\prime 1}$ & 2810 [2280-3110] & $3110[2406-3640]^{\prime 3}$ & 2720 [2120-3310] & $3090[2540-3620]^{15}$ \\
\hline IL2 & 10.6 [8.92-12.9] & $10.4[8.5-12.2]$ & 10.9 [8.83-12.4] & 11.1 [8.69-12.5] & $10[8.63-11.7]$ & $10.4[8.57-12.1]$ \\
\hline IL8 & 29.1 [23.7-34.3] & 31.2 [26.8-35.6] & 30.4 [23.9-34.8] & 32.4 [27.7-36.2] & 29.8 [22.9-33.8] & 30.9 [25.9-35.3] \\
\hline IL10 & 26.2 [20.9-31.5] & $22.3[17.7-27]^{11}$ & 27.8 [19.7-32.6] & $21.6[16.9-26.3]^{\prime 3}$ & 25.7 [19.1-30.3] & $23.5[18.5-28.1]$ \\
\hline IFNy & 18.4 [15.5-21.3] & $19.3[16-21.8]$ & 18.9 [16.7-22.3] & $20.2[17.3-22.4]$ & $17.9[14.7-21.8]$ & $21.1[17.4-24.3]^{12.5}$ \\
\hline M-CSF & 371 [320-448] & $402[345-484]^{11}$ & 378 [314-452] & $451[391-540]^{\wedge 2 * 3}$ & 394 [322-440] & $517[410-614]^{\star 2.4 .5}$ \\
\hline CX3CL1 & 520 [439-607] & 503 [427-579] & 553 [455-647] & 544 [409-597] & 546 [461-639] & 519 [447-602] \\
\hline CXCL10 & 18.6 [15.2-21.3] & 17.7 [15.1-20.5] & $19.5[16.3-22.1]$ & $18.2[15.8-21.3]$ & 17.9 [14.7-21.9] & $18.9[15.4-21.3]$ \\
\hline TGF $\beta 1$ & 21.4 [18.3-24.9] & $20.3[17.2-23.1]$ & $22.1[18.1-24.3]$ & $19.7[16.8-22.9]$ & 20.9 [17.9-24.5] & $20.6[17.7-23.3]$ \\
\hline Erythropoietin & 15.5 [10.2-20.3] & 15.7 [9.62-19.9] & $12.5[9.12-15.6]^{\wedge 1}$ & $17.2[12.9-22.3]^{\wedge 2 * 3}$ & $12.7[7.8-16.9]^{\wedge 1}$ & $20.3[16.2-24.7]^{\star 2.5 \wedge 4}$ \\
\hline
\end{tabular}

Note: significance of differences: ' $-<0.05, \wedge-<0.01,{ }^{*}-<0.001$ (comparison with the specified group); $1-7: 00$ a.m., dippers, $2-8: 00$ p.m, dippers, $3-7: 00$ a.m., non-dippers, 4 - 8:00 p.m., non-dippers, 5 - 7:00 a.m., night-peakers, 6 - 8:00 p.m, night-peakers. The data are presented as a median (Me) and an interquartile range [C25-C75] 
$\operatorname{IL} 1 \beta$ and IL1 $\alpha$ and a few other cytokines whose circadian dynamics remain understudied (LIF, sLIFr and M-CSF) significantly increase in the evening in hypertensive patients. In healthy individuals, evening concentrations of LIF, sLIFr, and M-CSF undergo a less pronounced rise $(<10 \%)$, whereas IL1 $\alpha$ and erythropoietin increase by 10-15\%. Importantly, patients with stage II EH (duration of 10-14 years, no antihypertensive therapy) demonstrate a more than $20 \%$ increase in the evening levels of IL1a, LIF, sLIFr, M-CSF, and erythropoietin. Such high values correlate with a rise in the concentrations of vasopressor peptides, in particular with ADMA and SDMA. ADMA competes with L-arginine for binding to eNOS [11]. SDMA is a structural ADMA isomer that has a role in arginine binding to a transmembrane transporter by limiting its availability to eNOS and curbing the subsequent synthesis of NO [12]. A substantial increase in the evening levels of the mentioned cytokines contributes to $\mathrm{EH}$ progression, which has been confirmed in a number of recent experimental studies. IL1 $\alpha$ has a direct stimulating effect on the proliferation of vascular smooth muscle cells, activates fibrosis and enhances the expression of angiotensin II and endothelin I receptor mRNA on the surface of the smooth muscle cells of the vascular wall [13]. Previously, we reported that IL $1 \alpha$ caused a secondary increase in LIF levels in the blood of patients with $\mathrm{EH}$ [14], which can stimulate the LIFmediated influx of $\mathrm{Ca}^{2+}$ and ERß-dependent activation of MAPK [15]. Growing concentrations of M-CSF inhibit eNOS activity [16] and suppress the mRNA expression of its own receptor IL34 (PTP-Z) [17]. These findings are consistent with our experimental data. A decline in IL34 concentrations occurring in the background of rising M-CSF [18] inhibits its protective effect on the brain. Together, these processes can cause vasodilation and increase the sensitivity of blood vessels to vasopressors. They unfold in the background of declining IL37 concentrations (the cytokine has a protective effect in patients with $\mathrm{EH}$ ) and stable IL10 levels and are more pronounced in individuals with a pathological daily BP cycle (non-dippers and night-peakers).

In the dippers whose BP dropped at nighttime by over $10 \%$, the studied cytokines, including IL1 $\beta, I L 18$, IL18BP, IL37, LIF, sLIFr, TNFa, sTNF-RI, IL2, IL8, IL10, IFNy, CX3CL1, CXCL10, TGF 31 , and M-CSF, followed the same pattern as in healthy individuals: except for IL6/sIL6r and erythropoietin, all these cytokines underwent a less than 15\% drop in the evening. A more than $20 \%$ increase in IL1 $\beta, I L 1 \alpha$, LIF, sLIFr, $\mathrm{M}-\mathrm{CSF}$ and erythropoietin concentrations registered in the evening is a potential isofactor that changes the tone of blood vessels and interferes with blood pressure regulation by the central nervous system. Under these circumstances, blood pressure does not decline sufficiently at night, and evening concentration of the mentioned cytokines rise by 35\%, which is associated with elevated nocturnal BP. These changes can be explained by the established correlations with vasopressor factors and are consistent with the experimental data provided above. Changes in the protective cytokine mechanisms that distinguish healthy individuals from patients with $\mathrm{EH}$ illustrate resistance to the effect of proinflammatory cytokines. In dippers, as well as in healthy volunteers, IL10 concentrations decline in the evening, but IL1ra does not go down, which is a compensatory antagonistic effect against growing IL1 $\beta$ and IL1 $\alpha$ (sIL6r does not decline in antihypertensive patients but does decrease in healthy individuals), which adds to the activity of IL6. In nondippers, evening concentrations of IL37 display a negative dynamic. In night-peakers, IL10 does not decline in the evening, suggesting a compensatory effect against the rising proinflammatory cytokines; however, IL1ra levels do drop in this group of patients.

\section{CONCLUSIONS}

We have identified a number of changes in the daily dynamics of peripheral blood cytokine concentrations in patients with stage II EH that are associated with abnormal daily BP cycles (non-dippers and night-peakers). Here, the major contribution is done by a more than $20 \%$ rise in LIF, sLIFr, M-CSF, IL1 $\alpha$, and erythropoietin. In the night-peaker group, the rise is over $35 \%$. Patients with a sufficient drop in BP at night (dippers) have higher concentrations of proinflammatory cytokines than healthy controls but the overall daily dynamics are the same in these two groups.

Understanding the pathophysiological role of cytokine levels and their fluctuations over a 24-h cycle in patients with stage II EH could inspire new methods for $\mathrm{EH}$ prevention, reducing end-organ damage and tailoring treatment strategies to an individual patient. This proves the importance of research into the dynamics of physiological parameters with respect to circadian rhythms.

\section{References}

1. Geiger SS, Fagundes CT, Siegel RM. Chrono-immunology: progress and challenges in understanding links between the circadian and immune systems. Immunology. 2015; 146 (3): 349-58.

2. Rico-Rosillo MG, Vega-Robledo GB. Sleep and immune system. Rev Alerg Mex. 2018; 65 (2): 160-70.

3. Labrecque N, Cermakian N. Circadian Clocks in the Immune System. J Biol Rhythms. 2015; 30 (4): 277-90.

4. Bennardo M, Alibhai F, Tsimakouridze E, et al. Day-night dependence of gene expression and inflammatory responses in the remodeling murine heart post-myocardial. Am J Physiol Regul Integr Comp Physiol. 2016; 311 (6): 1243-54.

5. Paganelli R, Petrarca C, Gioacchino M. Biological clocks: their relevance to immune-allergic diseases. Clin Mol Allerg. 2018; 16 (1). PMID: 29344005. DOI: 10.1186/s12948-018-0080-0.

6. Portaluppi F. The circadian organization of the cardiovascular system in health and disease. Indian J Exp Biol. 2014; 52 (5): 395-8.

7. Xing CY, Tarumi T, Meijers RL, et al. Arterial Pressure, Heart Rate, and Cerebral Hemodynamics Across the Adult Life Span. Hypertension. 2017; 69 (4): 712-20.

8. Cuesta M, Boudreau P, Dubeau-Laramee G, et al. Simulated

Night Shift Disrupts Circadian Rhythms of Immune Functions in Humans. J Immunol. 2016; 196 (6): 2466-75.

9. Su D, Song A, Yan B, et al. Circadian Blood Pressure Variations in Postmenopausal Females with Hypertension. Int Heart J. 2018; 59 (2): 361-6.

10. Sartini C, Whincup PH, Wannamethee SG, et al. Associations of time of day with cardiovascular disease risk factors measured in older men: results from the British Regional Heart Study. BMJ Open. 2017; 7 (11): e018264. DOI: 10.1136/bmjopen-2017-018264.

11. Shin S, Thapa SK, Fung H-L. Cellular interactions between L-arginine and asymmetric dimethylarginine: Transport and metabolism. PLoS ONE. 2017; 12 (5): e0178710. DOI:10.1371/ journal.pone.0178710.

12. Dahlem DP, Neiger R, Schweighauser A. Plasma Symmetric Dimethylarginine Concentration in Dogs with Acute Kidney Injury and Chronic Kidney Disease. J Veterin Int Med. 2017; 31 (3): 899-04.

13. Ahnstedt H, Stenman E, Cao L, et al. Cytokines and growth factors modify the upregulation of contractile endothelin ET(A) and $\mathrm{ET}(\mathrm{B})$ receptors in rat cerebral arteries after organ culture. Acta Physiol. 2012; 205 (2): 266-78. 
14. Radaeva OA, Simbircev AS. Gendernye osobennosti sistemy interlejkina-1 u zhenshchin s ehssencial'noj arterial'noj gipertenziej. Citokiny i vospalenie. 2014; 3 (13): 31-8. Russian.

15. Dey D, Shepherd A, Pachuau J, Martin M. Leukemia inhibitory factor regulates trafficking of T-type Ca2+ channels. Am J Physiol Cell Physiol. 2011; 300 (3): 576-87.

16. Hsu CP, Zhao JF, Lin SJ, et al. Asymmetric Dimethylarginine Limits the Efficacy of Simvastatin Activating Endothelial Nitric Oxide Synthase. J Am Heart Assoc. 2016; 5 (4): e003327. DOI: 10.1161/JAHA.116.003327.

\section{Литература}

1. Geiger SS, Fagundes CT, Siegel RM. Chrono-immunology: progress and challenges in understanding links between the circadian and immune systems. Immunology. 2015; 146 (3): 349-58.

2. Rico-Rosillo MG, Vega-Robledo GB. Sleep and immune system. Rev Alerg Mex. 2018; 65 (2): 160-70.

3. Labrecque N, Cermakian N. Circadian Clocks in the Immune System. J Biol Rhythms. 2015; 30 (4): 277-90.

4. Bennardo M, Alibhai F, Tsimakouridze E, et al. Day-night dependence of gene expression and inflammatory responses in the remodeling murine heart post-myocardial. Am J Physiol Regul Integr Comp Physiol. 2016; 311 (6): 1243-54

5. Paganelli R, Petrarca C, Gioacchino M. Biological clocks: their relevance to immune-allergic diseases. Clin Mol Allerg. 2018; 16 (1). PMID: 29344005. DOI: 10.1186/s12948-018-0080-0.

6. Portaluppi F. The circadian organization of the cardiovascula system in health and disease. Indian J Exp Biol. 2014; 52 (5): 395-8.

7. Xing CY, Tarumi T, Meijers RL, et al. Arterial Pressure, Heart Rate, and Cerebral Hemodynamics Across the Adult Life Span. Hypertension. 2017; 69 (4): 712-20.

8. Cuesta M, Boudreau P, Dubeau-Laramee G, et al. Simulated Night Shift Disrupts Circadian Rhythms of Immune Functions in Humans. J Immunol. 2016; 196 (6): 2466-75.

9. Su D, Song A, Yan B, et al. Circadian Blood Pressure Variations in Postmenopausal Females with Hypertension. Int Heart J. 2018; 59 (2): 361-6.

10. Sartini C, Whincup PH, Wannamethee SG, et al. Associations of time of day with cardiovascular disease risk factors measured in older men: results from the British Regional Heart Study. BMJ Open. 2017; 7 (11): e018264. DOI: 10.1136/bmjopen-2017-018264.

11. Shin S, Thapa SK, Fung H-L. Cellular interactions between
17. Hawley CA, Rojo R, Raper A. Csf1r-mApple Transgene Expression and Ligand Binding In Vivo Reveal Dynamics of CSF1R Expression within the Mononuclear Phagocyte System. J Immunol. 2018 Mar 15; 200 (6): 2209-23. DOI: 10.4049/jimmunol.1701488.

18. Radaeva OA, Simbircev AS. M-CSF, IL-34, VEGF-A kak faktory riska razvitiya infarkta miokarda, ostrogo narusheniya mozgovogo krovoobrashcheniya u bol'nyh ehssencial'noj arterial'noj gipertenziej. Rossijskij immunologicheskij zhurnal. 2015; 9 (1): 93-101. Russian.

L-arginine and asymmetric dimethylarginine: Transport and metabolism. PLoS ONE. 2017; 12 (5): e0178710. DOI:10.1371/ journal.pone.0178710.

12. Dahlem DP, Neiger R, Schweighauser A. Plasma Symmetric Dimethylarginine Concentration in Dogs with Acute Kidney Injury and Chronic Kidney Disease. J Veterin Int Med. 2017; 31 (3): 899-04.

13. Ahnstedt H, Stenman E, Cao L, et al. Cytokines and growth factors modify the upregulation of contractile endothelin ET(A) and $\mathrm{ET}(\mathrm{B})$ receptors in rat cerebral arteries after organ culture. Acta Physiol. 2012; 205 (2): 266-78.

14. Радаева О. А., Симбирцев А. С. Гендерные особенности системы интерлейкина-1 у женщин с эссенциальной артериальной гипертензией. Цитокины и воспаление. 2014; 3 (13): 31-8.

15. Dey D, Shepherd A, Pachuau J, Martin M. Leukemia inhibitory factor regulates trafficking of T-type Ca2+ channels. Am J Physiol Cell Physiol. 2011; 300 (3): 576-87.

16. Hsu CP, Zhao JF, Lin SJ, et al. Asymmetric Dimethylarginine Limits the Efficacy of Simvastatin Activating Endothelial Nitric Oxide Synthase. J Am Heart Assoc. 2016; 5 (4): e003327. DOI: 10.1161/JAHA.116.003327.

17. Hawley CA, Rojo R, Raper A. Csf1r-mApple Transgene Expression and Ligand Binding In Vivo Reveal Dynamics of CSF1R Expression within the Mononuclear Phagocyte System. J Immunol. 2018 Mar 15; 200 (6): 2209-23. DOI: 10.4049/jimmunol.1701488.

18. Радаева О. А., Симбирцев А. C. M-CSF, IL-34, VEGF-A как факторы риска развития инфаркта миокарда, острого нарушения мозгового кровообращения у больных эссенциальной артериальной гипертензией. Российский иммунологический журнал. 2015; 9 (1): 93-101. 